$\begin{array}{ll} & \text { Etnográfica } \\ \text { etnográfica } & \text { Revista do Centro em Rede de Investigação em }\end{array}$

Antropologia

vol. $16(2) \mid 2012$

Vol. $16(2)$

\title{
Patricia de Santana Pinho, Mama Africa: Reinventing Blackness in Bahia
}

\section{Samuel Weeks}

\section{OpenEdition \\ Journals}

Electronic version

URL: https://journals.openedition.org/etnografica/1575

DOI: 10.4000/etnografica. 1575

ISSN: 2182-2891

\section{Publisher}

Centro em Rede de Investigação em Antropologia

\section{Printed version}

Date of publication: 1 June 2012

Number of pages: 423-425

ISSN: 0873-6561

\section{Electronic reference}

Samuel Weeks, "Patricia de Santana Pinho, Mama Africa: Reinventing Blackness in Bahia", Etnográfica [Online], vol. 16 (2) | 2012, Online since 26 June 2012, connection on 10 February 2022. URL: http:// journals.openedition.org/etnografica/1575 ; DOI: https://doi.org/10.4000/etnografica.1575

\section{(c) (7) (8)}

Etnográfica is licensed under a Creative Commons Attribution-NonCommercial 4.0 International License. 
ao nível da preocupação dos prestadores de cuidados de saúde, é também nesta fase que os pais assumem consciente ou inconscientemente uma tomada de posição. O texto de Maria José Casa-Nova ilustra bem esta ambiguidade no contexto de famílias ciganas, em que existem crianças que não são vacinadas por "descuido" ou "desinteresse" da família (ideias manifestadas por alguns interlocutores da autora), mas, para outras, é o inverso que é privilegiado: vacinar é a expressão do cuidado, da proteção, mesmo quando implica a compra de vacinas que não são comparticipadas pelo Estado mas que se considera serem uma prevenção, um cuidado extra que se tem para com as crianças.

A questão da vacinação demonstra a sua complexidade - e talvez sejam os textos de Virgínia Calado e de Manuela Ivone Cunha e Jean-Yves Durand os que melhor a explicitam - no âmbito da recusa da vacinação enquanto expressão de agencialidade política. Tal acontece no sentido em que são aqueles que têm um maior conhecimento sobre os propósitos e efeitos da vacinação que a questionam e põem em causa todo o sistema político hegemónico no qual esse

Patricia de Santana Pinho

MAMA AFRICA:

REINVENTING BLACKNESS IN BAHIA

Durham, NC: Duke University Press,

2010, 280 pages,

ISBN: 9780822346463.

In Mama Africa, Brazilian social scientist Patricia de Santana Pinho details the influence that "Africa" has on conceptions of blackness in Bahia, the northeastern plano está inserido. Vacinar não representa então um cuidado acrescido, mas antes um risco desnecessário, e a autoridade médica é desafiada nos seus preceitos e convicções. Não vacinar, para além de uma escolha, torna-se um ato de resistência rara no contexto português. Assim, não estamos a falar de uma lógica economicista, como sucede noutros países, mas antes na consciência de si próprio e da gestão do corpo, na saúde e na doença. Ora, estamos antes de mais perante um tema que provoca e espoleta toda uma série de inquietações, não só em termos teóricos e académicos, mas também ao nível da sociedade civil, da comunidade médica e dos decisores políticos. Neste sentido, esta é uma obra que tem a potencialidade de catapultar essa discussão e contribuir para um conhecimento informado que não se confine nem à coleta de informação ad hoc e acrítica, nem à partilha de um modelo que, na prática, se desconhece.

\section{Catarina Frois}

Centro em Rede de Investigação em Antropologia, ISCTE - Instituto Universitário de Lisboa, Portugal catarina.frois@netcabo.pt

Brazilian state with the country's largest Afro-descendent population and a black culture known for its vibrancy. The receptiveness of Afro-Bahians to black cultural influences from abroad, coupled with the desire of outsiders to project African "tradition" and "purity" onto the state, has defined its place within the diasporic "black Atlantic". As such, Afro culture in Bahia influences, and is influenced by, the other nodes of the African diaspora in the New World (namely the USA, Cuba, and 
Jamaica), an interaction corroborated by the increasing presence of African-American "roots" tourists in the state. In this light, Pinho likens "African" Bahia to an imagined community, the solidarity necessary for which exists as an idea in the minds of its believers.

A central theme to Mama Africa is how the blocos afro, Bahia's Afrocentric and antiracist Carnival groups-cum-cultural organizations, consider Africanness, blackness, and themselves in relation to these concepts. In this context, the body assumes an essential role as the place where the blo$\cos$ afro seek to re-inscribe Africa through dance, song, religious practice, clothes, hairstyles, jewelry, and the celebration of bodily features such as skin color and hair texture. To Pinho, this ethnicized identity depends excessively on consumption and treads towards an exoticism all too easily gazed upon.

While lauding the blocos afro for resignifying the previously stigmatized black body, she documents the presence of an informal system of surveillance that monitors the adherence of members to Afro-aesthetic ideals. Bloco veterans encourage newcomers to adopt Afrocentric habitus, then subsequently lay claim to having brought out the "true" identity of their members. As Pinho sees it, the regulation of what is properly "black" and impurely "non-black" serves to undermine the diversity of the creative black experience in favor of a homogenous form of blackness. On page 96, she states, "Afrocentricity reduces Africa to a set of frozen and confining representations of blackness centered primarily on the body. The search for African genuineness is translated into the notion that to be black one must act, behave, and dress black, thus perpetuating the notion that blacks are all alike" (italics in original).

Moving from the surface of the body to its interior, Pinho analyzes how her interlocutors relate black skin and an "African" appearance to a black essence, a belief they articulate with the myth of Mama Africa, or the idea of Africa being alive in every black person. So ubiquitous is this myth among the bloco participants that it has become "common sense" as Gramsci would define it, an ideology constructed more by consent than coercion. Here, blood is the medium that transmits the aptitude for music and dance "inherent" to black people. The role of blocos afro, in turn, is to provide opportunities in which their members can act out these supposedly natural tendencies with the stated goal of "strengthening" a collective Afro-Brazilian identity.

Unsurprisingly, Pinho rejects this essentialism in favor of an explanation that cites how the "particularity" of the black experience informs the socially and historically constructed subjectivities of its actors. The thought that talent in music and dance are intrinsic to being black recalls racist stereotypes from the nineteenth century and defines race in terms of a simplistic culturenature binary. The consequence of this dynamic appears to bring about the opposite of the group's original objective, as the people whom the blocos afro wish to liberate are constrained instead. In this regard, Pinho reveals an inconsistency between the discourse and practice of the blocos, especially those that exclude people whom they regard as insufficiently black. As she stresses throughout the text, racism cannot be successfully "fought" by means of racialist practice.

Mama Africa's maternal and nurturing character troubles Pinho as well, which she believes serves to reinforce the notion that servitude is part of a black women's "nature". Compellingly, she contends that this myth results in an oppositional black culture that is susceptible to exploitation by commercial and political interests. 
To her, the essentialized notions of blackness found in Bahia too often merge with the idea of baianidade (Bahianness) promoted by the state and tourism industry, who for commercial ends readily circulate images of large black women in "African" dress and turbans. Unfortunately, as Pinho notes, "the enthusiasm demonstrated by the political elite toward the products of blackness has not been accompanied by an equivalent zeal for the human beings that produce such culture" (pp. 212-213).

Overall, Pinho succeeds in making accessible to Anglophone readers key concepts and debates in contemporary Brazilianist scholarship. "Race", "Africa", "blackness", "baianidade", and "racial harmony" remain in quotation marks throughout the text in order to emphasize the ambiguity and instability surrounding these terms. She addresses the changing dynamics, and at times controversial logic, behind current public policy discussions in Brazil, the most contentious of which seeks to assess racial inequality in a country in which notions of mestiçagem (ethnic admixture) and racial democracy are central to the national narrative. Too often, she fears, is "Africa" used to construct a blackness that enhances racial divisions rather than overcoming them. As a result, in her opinion, identity projects like those of the blocos afro serve to partition groups and limit the possibility of achieving an inclusive understanding of humanity.

Pinho is less successful in trying to buttress Mama Africa's theoretical discussion (based on the work of Gilroy, Hall, and Appiah) and cultural references with ethnographic accounts, some of which are too brief and lack depth. For example, the text's title alludes to the eponymous hit song by Chico César, in which Mama Africa is an exhausted proletarian who wraps packages at a chain store and prepares baby bottles for others' children. A discussion of the song, however, is limited to one paragraph in the introduction, and Pinho does not mention how her bloco afro informants would respond to unsentimental takes on Mama Africa like César's.

Ultimately, the text's strengths render this shortcoming of little consequence. Mama Africa will no doubt be an important reference to scholars studying ethnicity, race, nation, and diaspora at the global and local levels. Her demonstration of the ability of "celebration" to inadvertently perpetuate racism is a significant contribution, as is her observation of how "empowerment" discourses often do little to promote meaningful racial equality. That groups like the blocos afro can coexist in relative peace with an exploitative market and an indifferent state is indicative of a condition common to the age of identity politics: the likelihood of a person feeling empowered without actually being so.

\section{Samuel Weeks}

Instituto de Ciências Sociais, Universidade de Lisboa, Portugal ssweeks1@gmail.com 